\title{
Utility of Multimodality Imaging Based Target Volume Definition for Radiosurgery of Trigeminal Neuralgia: An Original Article
}

\author{
Ferrat Dincoglan, Selcuk Demiral, Omer Sager* and Murat Beyzadeoglu \\ Department of Radiation Oncology, University of Health Sciences, Gulhane Medical Faculty, Ankara, Turkey \\ *Corresponding author: Omer Sager, Department of Radiation Oncology, University of Health Sciences, Gulhane Medical \\ Faculty, Ankara, Turkey
}

\section{ARTICLE INFO}

Received: February 21, 2020

Published: 㠦 March 02, 2020

Citation: Ferrat D, Selcuk D, Omer S, Murat B. Utility of Multimodality Imaging Based Target Volume Definition for Radiosurgery of Trigeminal Neuralgia: An Original Article. Biomed J Sci \& Tech Res 26(2)-2020. BJSTR. MS.ID.004311.

Keywords: Trigeminal Neuralgia; Radiosurgery; Magnetic Resonance Imaging (MRI)

Abbreviations: MRI: Magnetic Resonance Imaging; CT: Computed Tomography; RF: Radio Frequency; MVD: Microvascular Decompression; AMOA: Arc Modulation Optimization Algorithm

\section{ABSTRACT}

Objective: Trigeminal neuralgia, also named "tic douloureux", is the facial pain which is usually one-sided in the distribution of 5th cranial nerve. After Leksell used radiosurgery as a therapeutic option for trigeminal neuralgia, this treatment modality has been accepted in the treatment of refractory pain caused by trigeminal neuralgia. Studies investigating the role of radiosurgery have rapidly increased regarding the poor results in pain control with invasive procedures, high rates of relapse and remarkable morbidity. Non-invasiveness and effectivity are the most important advantages of radiosurgery. The aim of this study is to assess incorporation of multimodality imaging into target volume definition of trigeminal neuralgia radiosurgery.

Materials and methods: Target definition with and without incorporation of Magnetic Resonance Imaging (MRI) was evaluated for linear accelerator-based radiosurgery of trigeminal neuralgia. Ground truth target volume to be used as the reference was defined by the board-certified treating physicians after comprehensive evaluation and consensus.

Results: Comparative assessment of target volume determination using Computed Tomography (CT) only imaging and CT-MR fusion-based imaging revealed that target volumes generated by CT-MR fusion-based imaging were identical to ground truth target volumes determined by the treatment team consensus.

Conclusion: MRI may serve as a valuable imaging modality improving target definition for linear accelerator-based radiosurgery of trigeminal neuralgia.

\section{Introduction}

Trigeminal neuralgia, also named "tic douloureux", is the facial pain which is usually one-sided in the distribution of 5th cranial nerve. The most commonly known cause of trigeminal neuralgia is the vascular compression of the trigeminal nerve $[1,2]$. The vascular compression is in superior cerebellar artery in $64 \%$ of the cases [3]. Vascular compression leads to continuous demyelination and remyelinisation cycles which causes myelinisation abnormalities of the nerve. High frequency ectopic impulses from this impaired myelinisation area may cause pain [4]. Medical treatment is the first step in trigeminal neuralgia that may lead to committing suicides. However, additional therapies are required in the setting of temporary response or refractory pain despite medical treatment. Carbamazepine, fenitoin, gabapentin, and baclofen may be used as medical treatment [5]. Invasive interventions are done when medical treatment is ineffective or when the side effects of medical treatment are unacceptable. Interventional procedures include percutaneous radiofrequency (RF) rhizotomy, percutaneous glycerol rhizotomy, percutaneous balloon micro compression and microvascular decompression (MVD). MVD is the most invasive procedure, however, repeating pain rates are lower with MVD [6]. Relapse is observed approximately in $30 \%$ of patients initially treated with MVD. 
Studies investigating the role of radiosurgery have rapidly increased regarding the poor results in pain control with invasive procedures, high rates of relapse and remarkable morbidity. Pain relief with radiosurgery in trigeminal neuralgia was first reported in $1951[7,8]$. A subsequent study revealed complete pain responses of 58\%-70\% with $\geq 70$ Gy single dose radiosurgery [9]. In this context, radiosurgery has been used as a treatment modality for management of trigeminal neuralgia as well as several other intracranial and extracranial benign and malign indications [10-32]. The aim of this study is to assess incorporation of multimodality imaging into target volume definition of trigeminal neuralgia radiosurgery.

\section{Materials and Methods}

Target definition with and without incorporation of Magnetic Resonance Imaging (MRI) was evaluated for linear acceleratorbased radiosurgery of trigeminal neuralgia in this study. Ground truth target volume to be used as the reference was defined by the board-certified treating physicians after comprehensive evaluation and consensus. Informed consents were provided before treatment, and management with radiosurgery was decided after thorough assessment including multidisciplinary collaboration of experts from neurosurgery, neuroradiology, and radiation oncology. A stereotactic head frame was affixed to the patients' skull under local anesthesia by use of 4 pins on the day of treatment. Computed Tomography (CT) simulation was performed at the CT simulator (GE Lightspeed RT, GE Healthcare, Chalfont St. Giles, UK). Planning CT images were sent to the contouring workstation (SimMD, GE, UK) for delineation of target volumes and critical structures. Target volume definition for radiosurgery was performed by use of CT simulation images only or fused CT and T1 gadolinium-enhanced MR images.

Target definition with CT only and by incorporation of CT-MR fusion was assessed comparatively. Definition of ground truth target volume was performed by the board-certified treating physicians after comprehensive evaluation and consensus to be used for actual treatment and comparison purposes. ERGO ++ (CMS, Elekta, UK) radiosurgery planning system was used for treatment planning. Synergy (Elekta, UK) Linear Accelerator (LINAC) was used for delivery of radiosurgery. Image Guided Radiation Therapy (IGRT) techniques including kV-CBCT (kilovoltage Cone Beam CT) and XVI (X-ray Volumetric Imaging, Elekta, UK) were used for treatment verification as a routine procedure.

\section{Results}

Target volume determination based on CT-only imaging and CT-MR fusion-based imaging was comparatively evaluated. Ground truth target volume defined by board certified treatment team after comprehensive assessment and colleague peer review was identical to target definition using CT-MR fusion-based imaging. Target volume delineation on the planning CT and MR images was optimized by selection of appropriate windows and levels in radiosurgery planning. Contouring accuracy was improved by use of sagittal and coronal images in addition to axial planning CT images. was achieved by use of the Arc Modulation Optimization Algorithm (AMOA) was utilized for optimization of target volume coverage and critical organ sparing. (Figure 1) shows axial planning CT image and (Figure 2) shows the corresponding axial MR image of the same patient with trigeminal neuralgia.

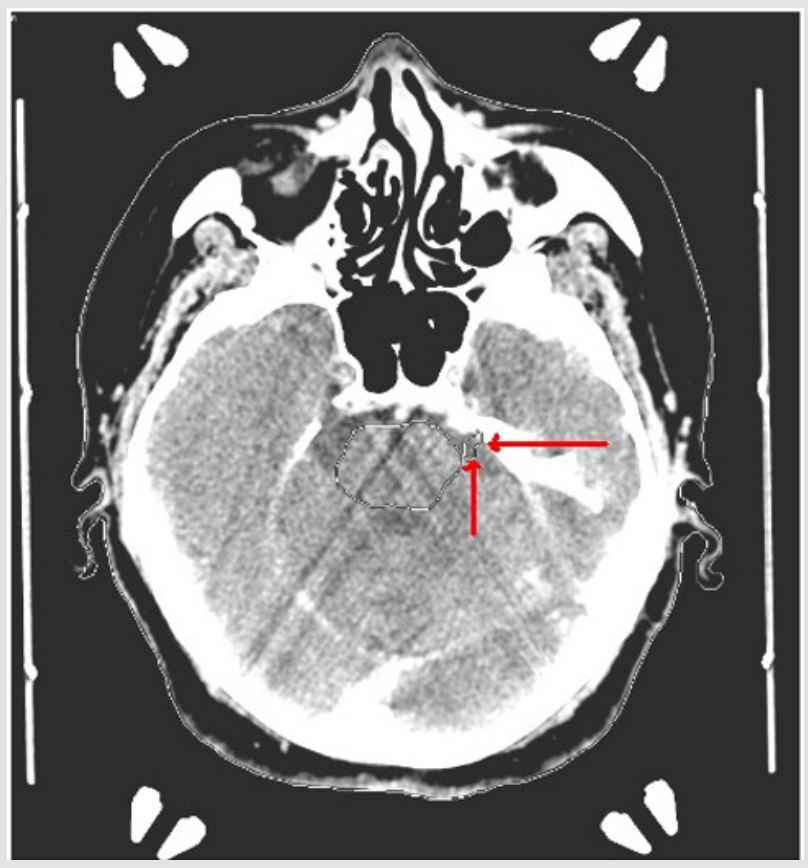

Figure 1: Axial planning CT image of a patient with trigeminal neuralgia.

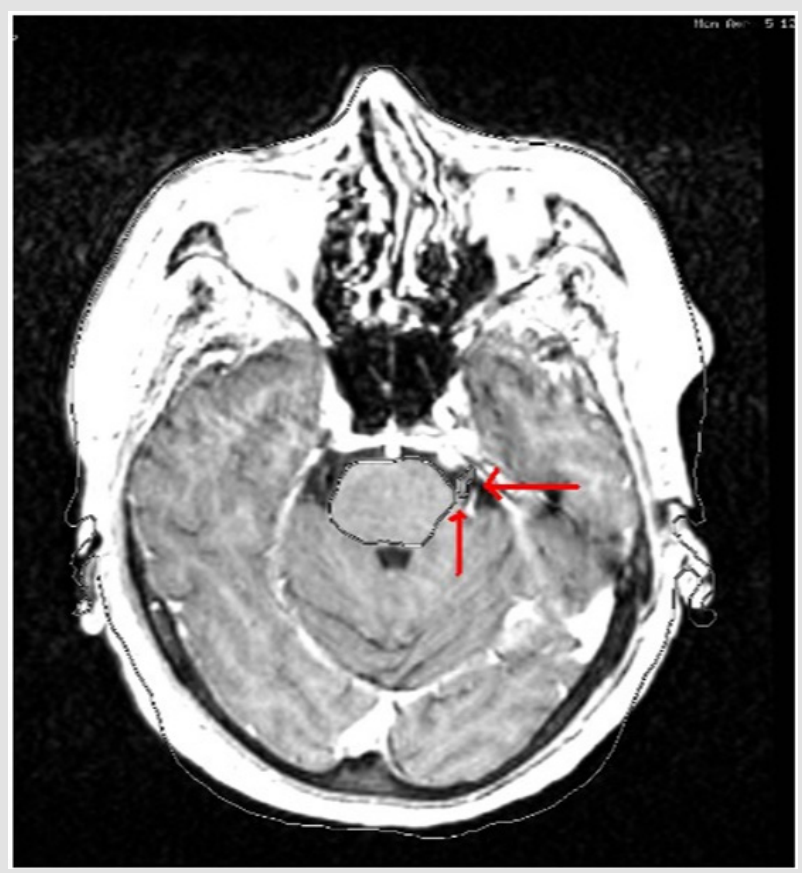

Figure 2: Corresponding axial MR image of the same patient with trigeminal neuralgia. 


\section{Discussion}

After Leksell used radiosurgery as a therapeutic option for trigeminal neuralgia, this treatment modality has been accepted in the treatment of refractory pain caused by trigeminal neuralgia. Non-invasiveness and effectivity are the most important advantages of SRS. Many studies evaluated the efficiency of radiosurgery in trigeminal neuralgia. Maesawa et al. [33] reported on 220 patients and $>50 \%$ pain relief was achieved in 139 patients. In the study by Kondziolka et al. [34] in 1996, 50 patients from 5 institutions were treated with SRS using a dose of 60-90 Gy. At a median follow-up of 18 months, excellent pain relief was achieved in 58\% of patients. This multi-institutional study revealed decreased effect of SRS on pain relief at maximal doses lower than 70 Gy [34]. Young et al. [35] and Zheng et al. [36] found SRS to be effective in the treatment of trigeminal neuralgia in their studies. Effect of the length of the irradiated nerve segment on treatment in SRS for trigeminal neuralgia is controversial. Flickinger et al. [37] used single and double isocenter in the treatment of 57 patients with trigeminal neuralgia. The highest single dose delivered was 75 Gy.

Median follow-up of 26 months revealed no significant improvement in pain response. Facial numbness and paresthesia were correlated with the length of the irradiated nerve segment [37]. In a study by Riesenberger et al. [38] 53 patients with trigeminal neuralgia were treated with single dose frame-based radiosurgery with a follow-up of at least 36 months. Median maximal dose was $80 \mathrm{~Gy} .31$ patients had significant pain relief after 48 months of follow-up in the study [38]. These results are similar to those achieved with MVD and rhizotomy. However, $36 \%$ of patients developed facial numbness after treatment. Kondziolka et al. [39] reported on 503 patients resistant to medical treatment who were treated with radiosurgery. 205 patients had undergone previous surgery and relapsed. Maximal dose was 80 Gy. $85 \%$ of patients had pain relief with or without medical treatment [39]. In this study, we assessed incorporation of multimodality imaging into target volume definition of trigeminal neuralgia radiosurgery. Indeed, usefulness of neuroimaging with MRI for definition of central nervous system radiotherapy and radiosurgery target volumes has been an important focus of research in the literature [40-49]. Our results appear to be compatible to these studies supporting the incorporation of MRI in radiosurgery treatment planning. Ground truth target volumes determined by comprehensive evaluation, consensus and colleague peer review were identical to target volumes defined based on CT-MR fusion-based imaging.

\section{Conclusion}

In conclusion, our study supports the utilization of MRI to improve target definition for linear accelerator-based radiosurgery of trigeminal neuralgia despite the need for further studies.

\section{References}

1. Barker FG, Jannetta PJ, Bissonette DJ, Larkins MV, Jho HD, et al. (1996) The long-term outcome of microvascular decompression for trigeminal neuralgia. N Engl J Med 334(17): 1077-1083.
2. Young RF, Vermeulen SS, Grimm P, Blasko J, Posewitz A, et al. (1996) Gamma knife radiosurgery for treatment of trigeminal neuralgia: Idiopathic and tumor related. Neurology 48: 608-614.

3. Anderson VC, Berryhill PC, Sandquist MA, Ciaverella DP, Nesbit GM, et al. (2006) High resolution three-dimensional magnetic resonance angiography and three-dimensional spoiled gradient-recalled imaging in the evaluation of neurovascular compression in patients with trigeminal neuralgia: a double-blind pilot study. Neurosurgery. Apr 58(4): 666-673.

4. Burchiel KJ (1980) Abnormal impulse generation in focally demyelinated trigeminal roots. J Neurosurg. Nov 53(5): 674-683.

5. Lunsford LD, Apfelbaum RI (1985) Choice of surgical therapeutic modalities for treatment of trigeminal neuralgia: Microvascular decompression, percutaneous retrogasserian thermal, or glycerol rhizotomy. Clin Neurosurg 32: 319-333.

6. Murali R, Rovit RL (1996) Are peripheral neurectomies of value in the treatment of trigeminal neuralgia? An analysis of new cases and cases involving previous radiofrequency gasserian thermocoagulation. J Neurosurg. Sep 85(3): 435-437.

7. Leksell L (1971) Stereotaxic radiosurgery and trigeminal neuralgia. Acta Chir Scand 37: 311-314.

8. Leksell L (1951) The stereotaxic method and radiosurgery of the brain. Acta Chir Sand 102: 316-319.

9. Kondziolka D, Perez B, Flickinger JC, Habeck M, Lunsford LD, et al. (1998) Gamma knife radiosurgery for trigeminal neuralgia-Results and expectations. Arch Neurol 55(12): 1524-1529.

10. Sager O, Dincoglan F, Demiral S, Uysal B, Gamsiz H, et al. (2018) Radiation Therapy (RT) for Diffuse Intrinsic Pontine Glioma (DIPG) in Children. Arch Can Res 6(3): 14.

11. Sager O, Dincoglan F, Demiral S, Uysal B, Gamsiz H, et al. (2018) A concise review of immunotherapy for glioblastoma. Neuroimmunol Neuroinflammation 5: 25.

12. Dincoglan F, Sager O, Uysal B, Demiral S, Gamsiz H, et al. (2019) Evaluation of hypo fractionated stereotactic radiotherapy (HFSRT) to the resection cavity after surgical resection of brain metastases: A single center experience. Indian J Cancer 56(3): 202-206.

13. Demiral S, Dincoglan F, Sager O, Uysal B, Gamsiz H, et al. (2018) Contemporary Management of Meningiomas with Radiosurgery. Int J Radiol Imaging Technol 80(2): 187-190.

14. Dincoglan F, Sager O, Demiral S, Uysal B, Gamsiz H, et al. (2017) Radiosurgery for recurrent glioblastoma: A review article. Neurol Disord Therap 1: 1-5.

15. Demiral S, Dincoglan F, Sager O, Gamsiz H, Uysal B, et al. (2016) Hypofractionated stereotactic radiotherapy (HFSRT) for who grade I anterior clinoid meningiomas (ACM). Jpn J Radiol 34(11): 730-737.

16. Dincoglan F, Beyzadeoglu M, Sager O, Demiral S, Gamsiz H, et al. (2015) Management of patients with recurrent glioblastoma using hypofractionated stereotactic radiotherapy. Tumori 101(2): 179-184.

17. Gamsiz H, Beyzadeoglu M, Sager O, Demiral S, Dincoglan F, et al. (2015) Evaluation of stereotactic body radiation therapy in the management of adrenal metastases from non-small cell lung cancer. Tumori 101(1): 98103.

18. Demiral S, Beyzadeoglu M, Sager O, Dincoglan F, Gamsiz H, et al. (2014) Evaluation of linear accelerator (linac)-based stereotactic radiosurgery (srs) for the treatment of craniopharyngiomas. UHOD-Uluslararasi Hematoloji-Onkoloji Dergisi 24: 123-129.

19. Dincoglan F, Sager O, Gamsiz H, Uysal B, Demiral S, et al. (2014) Management of patients with $\geq 4$ brain metastases using stereotactic radiosurgery boost after whole brain irradiation. Tumori 100(3): 302306.

20. Gamsiz H, Beyzadeoglu M, Sager O, Dincoglan F, Demiral S, et al. (2014) Management of pulmonary oligometastases by stereotactic body radiotherapy. Tumori $100(2): 179-183$. 
21. Sager O, Dincoglan F, Beyzadeoglu M (2015) Stereotactic radiosurgery of glomus jugulare tumors: Current concepts, recent advances and future perspectives. CNS Oncol 4(2): 105-114.

22. Sager O, Beyzadeoglu M, Dincoglan F, Gamsiz H, Demiral S, et al. (2014) Evaluation of linear accelerator-based stereotactic radiosurgery in the management of glomus jugulare tumors. Tumori 100(2): 184-188.

23. Sager O, Beyzadeoglu M, Dincoglan F, Uysal B, Gamsiz H, et al. (2014) Evaluation of linear accelerator (LINAC)-based stereotactic radiosurgery (SRS) for cerebral cavernous malformations: A 15-year single-center experience. Ann Saudi Med 34(1): 54-58.

24. Demiral S, Beyzadeoglu M, Uysal B, Oysul K, Kahya YE, et al. (2013) Evaluation of stereotactic body radiotherapy (SBRT) boost in the management of endometrial cancer. Neoplasma 60(3): 322-327.

25. Dincoglan F, Beyzadeoglu M, Sager O, Uysal B, Demiral S, et al. (2013) Evaluation of linear accelerator-based stereotactic radiosurgery in the management of meningiomas: A single center experience. J BUON 18(3): 717-722.

26. Sager O, Beyzadeoglu M, Dincoglan F, Demiral S, Uysal B, et al. (2013) Management of vestibular schwannomas with linear accelerator-based stereotactic radiosurgery: A single center experience. Tumori 99(5): 617-622.

27. Dincoglan F, Sager O, Gamsiz H, Uysal B, Demiral S, et al. (2012) Stereotactic radiosurgery for intracranial tumors: A single center experience. Gulhane Med J 54(3): 190-198.

28. Dincoglan F, Sager O, Gamsiz H, Demiral S, Uysal B, et al. (2012) Management of arteriovenous malformations by stereotactic radiosurgery: A single center experience. UHOD-Uluslararasi Hematoloji-Onkoloji Dergisi 22: 107-112.

29. Dincoglan F, Beyzadeoglu M, Sager O, Oysul K, Sirin S, et al. (2012) Image-guided positioning in intracranial non-invasive stereotactic radiosurgery for the treatment of brain metastasis. Tumori 98(5): 630635.

30. Sirin S, Oysul K, Surenkok S, Sager O, Dincoglan F, et al. (2011) Linear accelerator-based stereotactic radiosurgery in recurrent glioblastoma: A single center experience. Vojnosanit Pregl 68(11): 961-966.

31. Dincoglan F, Sager O, Demiral S, Gamsiz H, Uysal B, et al. (2019) Fractionated stereotactic radiosurgery for locally recurrent brain metastases after failed stereotactic radiosurgery. Indian J Cancer 56(2): 151-156.

32. Surenkok S, Sager O, Dincoglan F, Gamsiz H, Demiral S, et al. (2012) Stereotactic radiosurgery in pituitary adenomas: A single center experience. UHOD-Uluslararasi Hematoloji-Onkoloji Dergisi 22: 255260.

33. Maesawa S, Salame C, Flickinger JC, Pirris S, Kondziolka D, et al. (2001) Clinical outcomes after stereotactic radiosurgery for idiopathic trigeminal neuralgia. J Neurosurg 94(1): 14-20.

34. Kondziolka D, Lunsford L, Flickinger J, Young R, Vermeulen S, et al. (1996) Stereotactic radiosurgery for trigeminal neuralgia: A multiinstitutional study using gamma knife unit. J Neurosurg 84: 940-945.

35. Young RF, Vermeulen SS, Grimm P, Blasko J, Posewitz A, et al (1997) Gamma knife radiosurgery for treatment of trigeminal neuralgia. Neurology 48: 608-614.
36. Zheng LG, Xu DS, Kang CS, Zhang ZY, Li YH, et al. (2001) Stereotactic radiosurgery for primary trigeminal neuralgia using the Leksell Gamma unit. Stereotact Funct Neurosurg 76: 29-35.

37. Flickinger JC, Polloek BE, Kondziolka D, Phuong LK, Foote RL, et al. (2001) Does increased nerve length within the treatment volume improve trigeminal neuralgia radiosurgery? A prospective double-blind randomized study. Int J Radiat Oncol Biol Phys 51: 449-454.

38. Riesenburger RI, Hwang SW, Schirmer CM, Zerris V, Wu JK, et al. (2010) Outcomes following single-treatment Gamma Knife surgery for trigeminal neuralgia with a minimum 3-year follow-up. J Neurosurg. 112(4): 766-771.

39. Kondziolka D, Zorro O, Lobato Polo J, Kano H, Flannery TJ, et al. (2010) Gamma Knife stereotactic radiosurgery for idiopathic trigeminal neuralgia. J Neurosurg 112(4): 758-765.

40. Dincoglan F, Sager O, Demiral S, Beyzadeoglu M (2019) Incorporation of Multimodality Imaging in Radiosurgery Planning for Craniopharyngiomas: An Original Article. SAJ Cancer Sci 6: 103.

41. Demiral S, Sager O, Dincoglan F, Beyzadeoglu M (2019) Assessment of Computed Tomography (CT) And Magnetic Resonance Imaging (MRI) Based Radiosurgery Treatment Planning for Pituitary Adenomas. Canc Therapy \& Oncol Int J 13(2).

42. Beyzadeoglu M, Sager O, Dincoglan F, Demiral S (2019) Evaluation of Target Definition for Stereotactic Reirradiation of Recurrent Glioblastoma. Arch Can Res 7(1): 3.

43. Sager O, Dincoglan F, Demiral S, Beyzadeoglu M (2019) Evaluation of Radiosurgery Target Volume Determination for Meningiomas Based on Computed Tomography (CT) And Magnetic Resonance Imaging (MRI). Cancer Sci Res Open Access 5(2): 1-4

44. Dincoglan F, Sager O, Demiral S, Beyzadeoglu M (2019) Multimodality Imaging for Radiosurgical Management of Arteriovenous Malformations. Asian Journal of Pharmacy, Nursing and Medical Sciences 7(1): 7-12.

45. Demiral S, Sager O, Dincoglan F, Beyzadeoglu M (2019) Assessment of target definition based on Multimodality imaging for radiosurgical Management of glomus jugulare tumors (GJTs). Cancer Ther Oncol Int J 15(2): 555909.

46. Sager O, Dincoglan F, Demiral S, Gamsiz H, Uysal B, et al. (2019) Utility of Magnetic Resonance Imaging (Imaging) in Target Volume Definition for Radiosurgery of Acoustic Neuromas. Int J Cancer Clin Res 6: 119.

47. Sager O, Dincoglan F, Demiral S, Gamsiz H, Uysal B, et al. (2019) Evaluation of the Impact of Magnetic Resonance Imaging (MRI) on Gross Tumor Volume (GTV) Definition for Radiation Treatment Planning (RTP) of Inoperable High-Grade Gliomas (HGGs). Concepts in Magnetic Resonance Part A 2019.

48. Demiral S, Sager O, Dincoglan F, Uysal B, Gamsiz H, et al. (2018) Evaluation of Target Volume Determination for Single Session Stereotactic Radiosurgery (SRS) of Brain Metastases. Canc Therapy \& Oncol Int J 12(5): 555848.

49. Sager O, Demiral S, Dincoglan F, Beyzadeoglu M (2020) Target Volume Definition for Stereotactic Radiosurgery (SRS) Of Cerebral Cavernous Malformations (CCMs). Canc Therapy \& Oncol Int J 15(4): 555917. 
ISSN: 2574-1241

DOI: 10.26717/BJSTR.2020.26.004311

Omer Sager. Biomed J Sci \& Tech Res

(c) (P) This work is licensed under Creative

Submission Link: https://biomedres.us/submit-manuscript.php

$\begin{array}{ll}\text { BIOMEDICAL } & \text { Assets of Publishing with us } \\ \text { RESEARCHES } & \text { - Global archiving of articles } \\ \text { - Immediate, unrestricted online access } \\ \text { - Rigorous Peer Review Process }\end{array}$

